\title{
Arginine hypomethylation-mediated proteasomal degradation of histone H4-an early biomarker of cellular senescence
}

\author{
Cong Lin ${ }^{1} \cdot$ Hongxin $\mathrm{Li}^{1}$ - Jiwei Liu ${ }^{2}$ Q Qianying $\mathrm{Hu}^{1} \cdot$ Shuai Zhang ${ }^{2} \cdot \mathrm{Na} \mathrm{Zhang}^{2}$ - Lingxia Liu' ${ }^{1}$ Yingjie Dai ${ }^{1}$. \\ Donghui $\mathrm{CaO}^{3} \cdot{\text { Xiaoxue } \mathrm{Li}^{1} \cdot \text { Baiqu Huang }}^{2} \cdot$ Jun $\mathrm{Lu}^{2} \cdot \mathrm{Yu} \mathrm{Zhang}^{1}$
}

Received: 9 August 2019 / Revised: 6 May 2020 / Accepted: 11 May 2020 / Published online: 23 May 2020

(c) The Author(s), under exclusive licence to ADMC Associazione Differenziamento e Morte Cellulare 2020

\begin{abstract}
Senescence is accompanied with histones level alteration; however, the roles and the mechanisms of histone reduction in cellular senescence are largely unknown. Protein arginine methyltransferase 1 (PRMT1) is the major enzyme that generates monomethyl and asymmetrical dimethyl arginine. Here we showed that abrogation of PRMT1-mediated senescence was accompanied with decreasing histone $\mathrm{H} 4$ level. Consistently, under multiple classic senescence models, H4 decreasing was also been found prior to the other 3 core histones. Noticeably, asymmetric demethylation of histone $\mathrm{H} 4$ at arginine 3 (H4R3me2as), catalyzed by PRMT1, was decreased prior to histone H4. In addition, we showed that the PRMT1-mediated $\mathrm{H} 4 \mathrm{R} 3 \mathrm{me} 2 \mathrm{as}$ maintained $\mathrm{H} 4$ stability. Reduction of H4R3me2as level increased the interaction between proteasome activator PA200 and histone $\mathrm{H} 4$, which catalyzes the poly-ubiquitin-independent degradation of $\mathrm{H} 4$. Moreover, $\mathrm{H} 4$ degradation promoted nucleosome decomposition, resulting in increased senescence-associated genes transcription. Significantly, H4 was restored by 3 well-informed anti-aging drugs (metformin, rapamycin, and resveratrol) much earlier than other senescence markers detected under $\mathrm{H}_{2} \mathrm{O}_{2}$-induced senescence. Thus, we uncovered a novel function of $\mathrm{H} 4 \mathrm{R} 3 \mathrm{me} 2 \mathrm{as}$ in modulation of cellular senescence via regulating $\mathrm{H} 4$ stability. This finding also points to the value of histone $\mathrm{H} 4$ as a senescence indicator and a potential anti-aging drug screening marker.
\end{abstract}

\section{Introduction}

Cellular senescence is an irreversible cell cycle arrest process. Multiple factors can trigger senescence including

Edited by G. Del Sal

Supplementary information The online version of this article (https:// doi.org/10.1038/s41418-020-0562-8) contains supplementary material, which is available to authorized users.

Jun Lu

luj809@nenu.edu.cn

$\triangle$ Yu Zhang

zhangy288@nenu.edu.cn

1 The Key Laboratory of Molecular Epigenetics of Ministry of Education (MOE), Northeast Normal University,

Changchun, China

2 The Institute of Genetics and Cytology, Northeast Normal University, Changchun, China

3 Pathological Diagnostic Center, First Hospital of Jilin University, Changchun, China telomere shortening, oncogenic signaling, oxidative stress, and DNA damage [1]. Characteristic features of senescent cells include cell cycle arrest, active DNA damage response (DDR), enhanced senescence-associated secretory phenotype (SASP), senescence-associated $\beta$-galactosidase (SA- $\beta$-gal) activity, and chromatin structure changes. Chromatin structure change is partially mediated by altering its constitutive components such as histones. For example, late-passage cells senescence displays reduced levels of core $\mathrm{H} 3$ and $\mathrm{H} 4$ histone components of the nucleosome [2]. Furthermore, the loss of core histones with aging appears to be due to the gain of $\mathrm{H} 3 \mathrm{~K} 27 \mathrm{me} 3$ mark at the promoter of histones genes in mammalian muscle stem cells [3]. This suggests that a shift of chromatin state at specific loci may precede the reduction of nucleosome occupancy during aging. Nucleosome occupancy decrease has also been demonstrated to be associated with global upregulation of gene expression with age in yeast and mammalian livers [4, 5], while ameliorating this loss in yeast extends lifespan [6]. Together, these data show that senescence is accompanied with histone level alteration; however, the roles and the 
mechanisms of histone reduction in cellular senescence are far from elucidated.

Histone tails protruding from the nucleosomes are targets for various post-translational modifications (PTMs), including phosphorylation, acetylation, methylation, and ubiquitylation [7]. Histone PTMs can directly influence the stability of histones. As reported, chronic oxidative stress enhances the $\mathrm{H} 2 \mathrm{AX}$ interaction with the $\mathrm{E} 3$ ubiquitin ligase RNF168, promotes H2AX poly-ubiquitination and its degradation by the proteasome, and results in a steady decrease in H2AX protein level, which in turn enhances chemosensitivity in breast cancer patients [8]. In addition, phosphorylation of histones by Rad53 enhances excess (non-chromatin bound) histones associate with the ubiquitin-conjugating enzymes (E2) Ubc4 and Ubc5, as well as the ubiquitin ligase (E3) Tom1 promotes excess histones poly-ubiquitination and its degradation by the proteasome in yeast [9]. Moreover, special forms of proteasomes, which contain PA200/Blm10, specifically catalyze the acetylation-dependent, but not poly-ubiquitinationdependent, degradation of the core histones during somatic DNA damage response and spermatogenesis [10]. To date, whether histone arginine methylation influences the stability of histones remains elusive.

The protein arginine methyltransferases (PRMTs), a family of enzymes catalyzing arginine methylation, have been reported to methylate a variety of protein substrates in multiple cellular processes, including RNA processing, gene transcription, DNA damage repair, signal transduction and protein translocation [11]. PRMT1 is a predominant arginine methyltransferase in human, which mediates asymmetric dimethylation of histone $\mathrm{H} 4$ at arginine 3 (H4R3me2as), a critical modification for activing transcription [12, 13]. Studies over the past decades also linked PRMT1 to aging and cellular senescence. PRMT1 methylates FoxO and blocks its phosphorylation to reduce FoxO protein degradation, thus leading to life span extension of diapause-destined pupae [14]. PRMT1 can also methylate DAF-16, block its phosphorylation by AKT, increase the expression of longevity-related genes, leading to life span extension of $C$. elegans [15]. At the cellular level, significant reduction of PRMT1 and asymmetric arginine methylation was seen during senescence of WI-38 fibroblasts [16]. Our previous study also indicated that depletion of PRMT1 arrested breast cancer cell growth and induced cellular senescence [17]. However, the roles of PRMT1mediated H4R3me2as in cellular senescence remain largely unknown.

The present study uncovered a novel mechanism for H4 stability regulation mediated by arginine methylation during senescence. Histone $\mathrm{H} 4$ degradation further promotes senescence-associated genes transcription, resulting in senescence. More importantly, we found that $\mathrm{H} 4$ also rapidly responded to anti-aging drugs, and was restored by all the 3 anti-aging drugs used, much earlier than other senescence markers detected under $\mathrm{H}_{2} \mathrm{O}_{2}$-induced senescence. These results implicate that histone $\mathrm{H} 4$ is an early senescence-associated marker, and may become a potential anti-aging drug screening target.

\section{Results}

\section{Depletion of PRMT1 induces fibroblasts senescence with reduction of histone $\mathrm{H} 4$}

Our previous study showed that inhibition of PRMT1 arrested breast cancer cell growth and induced cellular senescence [17]. In this study, we further investigated the mechanisms of PRMT1-mediated H4R3me2as in human fibroblasts senescence regulation. We first examined the activity of senescence-associated $\beta$-galactosidase (SA- $\beta$-gal) in PRMT1 knockdown IMR90 cells. The results revealed a remarkably intensified SA- $\beta$-gal staining in PRMT1 knockdown cells compared with control cells (Fig. 1a). Meanwhile, depletion of PRMT1 significantly reduced Ki67 positive staining cells, accompanied with Cyclin A2 and Lamin B1 downregulation, and a concurrent p21 and $\gamma$ H2AX upregulation (Fig. 1b, c), which confirms that depletion of PRMT1 induces fibroblasts senescence. PRMT1 inhibition significantly decreased H4R3me2as level, together with a dramatic decline of $\mathrm{H} 4$ level while the other 3 core histones remained unchanged (Fig. 1c). Similar results were also seen in CRL-1474 human skin fibroblast cells (Fig. 1d and Supplementary Fig. 1). Taken together, these data indicate that inhibition of the PRMT1-induced fibroblasts senescence is accompanied with $\mathrm{H} 4$ reduction.

\section{Reduction of histone $\mathrm{H} 4$ prior to the other 3 core histones during cellular senescence and aging}

Since the senescence induced by PRMT1 inhibition occurred concurrently with reduction of $\mathrm{H} 4$, we next wondered if this is a common phenomenon in other senescence models. We tested this in replicative senescence by harvesting IMR90 cells every 5 population doublings (PDs) beginning with PD20. The proportion of cells positive for SA- $\beta$-gal activity remarkably increased and the Ki67 expression significantly reduced at PD40 (Supplementary Fig. 2a, b). Also, Cyclin A2 was reduced, while $\gamma$-H2AX and p21 were increased at PD35. Lamin B1 was reduced, while IL6 and p16 were increased at PD40. Significantly, $\mathrm{H} 4$ decreased from PD35, while the other 3 core histones were not found to be altered at PD35 but reduced at PD40 (Fig. 2a). Next, we used $\mathrm{H}_{2} \mathrm{O}_{2}$, Etoposide, and Ras, to trigger IMR90 fibroblast premature senescence. Cellular 


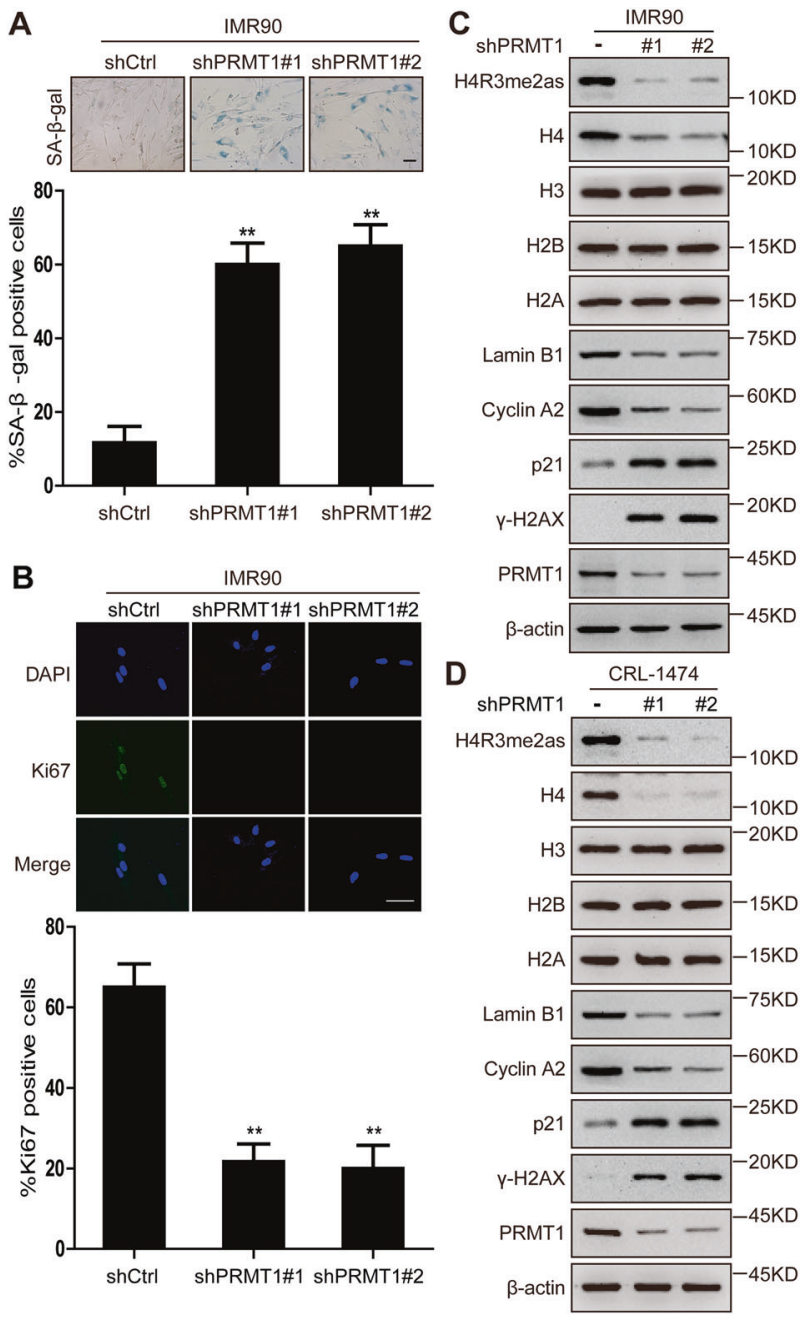

Fig. 1 Knockdown of PRMT1 promoted cellular senescence and decreased histone $\mathbf{H 4}$ level. a IMR90 cells were infected with control shRNA (shCtrl) or PRMT1 shRNA (shPRMT1\#1 or \#2) for 4 days, cells were subjected to SA- $\beta$-gal staining. Top panel showed the representative images. The percentage of SA- $\beta$-gal positive cells was calculated (lower). Scale bars: $100 \mu \mathrm{m}$. b IMR90 cells were infected with control shRNA (shCtrl) or PRMT1 shRNA (shPRMT1\#1 or \#2) for 4 days, expression of Ki67 was analyzed by immunofluorescence. Top panel showed the representative images. The percentage of the Ki67 postitive cells was calculated (lower). Scale bars: $50 \mu \mathrm{m}$. c IMR90 cells were infected with control shRNA (shCtrl) or PRMT1 shRNA (shPRMT1\#1 or \#2) for 4 days, the level of PRMT1, CyclinA2, Lamin B1, p21, $\gamma-\mathrm{H} 2 \mathrm{AX}, \mathrm{H} 2 \mathrm{~A}, \mathrm{H} 2 \mathrm{~B}, \mathrm{H} 3, \mathrm{H} 4$, and H4R3me2as was detected by western blotting. d CRL-1474 cells were infected with control shRNA (shCtrl) or PRMT1 shRNA (shPRMT1\#1 or \#2) for 4 days, the level of PRMT1, Cyclin A2, Lamin B1, p21, $\gamma$ $\mathrm{H} 2 \mathrm{AX}, \mathrm{H} 2 \mathrm{~A}, \mathrm{H} 2 \mathrm{~B}, \mathrm{H} 3, \mathrm{H} 4$, and H4R3me2as was detected by western blotting. Each experiment was repeated at least 3 times. Error bars, mean $\pm \mathrm{SD}, * * P<0.01$

senescence was assessed by SA- $\beta$-gal, Ki67, Lamin B1, Cyclin A2, $\gamma$-H2AX, IL6, p21, and p16 at indicated time points (Fig. 2b-d and Supplementary Fig. 2c-h). All the 3 classic premature senescence models displayed loss of $\mathrm{H} 4$ sooner than the other 3 core histones, similar to that seen in spontaneous senescence (Fig. 2b-d). Further, we addressed whether these findings are relevant to normal human aging. We examined four core histones expressions in skin sections of eyelid from different normal donors (aged 24, aged 45, aged 50 and aged 52). Immunohistochemical staining revealed a reduction of $\mathrm{H} 4$ in relatively aged skin of eyelid (aged 50 and aged 52), while the other 3 core histones were not found to be altered (Fig. 2e). To investigate whether the reduction of $\mathrm{H} 4$ was specific to senescent cells, we also detected the level of histones under quiescence or apoptosis. IMR90 fibroblasts were kept under serum starvation to enter quiescence status, or treated with $200 \mu \mathrm{M}$ Etoposide or $1.5 \mathrm{mM} \mathrm{H}_{2} \mathrm{O}_{2}$ for apoptosis. Under these conditions, the four core histones remained unaltered (Supplementary Fig. 3). These data suggest that the decline of $\mathrm{H} 4$ prior to other 3 histones is a part of the senescence program, irrespective of the senescence inducers, and this may implicate histone $\mathrm{H} 4$ as an early senescence-associated marker.

\section{PA200-proteasome mediates histone $\mathrm{H} 4$ degradation during senescence}

Having confirmed the $\mathrm{H} 4$ reduction during senescence, we next sought to gain insight into the mechanism underlying this phenomenon. We first detected $\mathrm{H} 4$ transcription level during senescence. We found that $\mathrm{H}_{2} \mathrm{O}_{2}$ treatment, Ras overexpression, or PRMT1 knockdown had little effect on the transcription level of H4 mRNA (Fig. 3a, b and Supplementary Fig. 4a), which suggests that $\mathrm{H} 4$ reduction might be regulated at the post-translational level. The lysosomes and proteasome mediate intracellular protein degradation. To test whether lysosomes are involved in processing of $\mathrm{H} 4$ during IMR90 senescence, we treated the cells with Bafilomycin A1 (Baf A1), an inhibitor of lysosome acidification. Bafilomycin A1 treatment did not antagonize the decrease of $\mathrm{H} 4$ (Fig. 3c, $\mathrm{d}$ and Supplementary Fig. 4b), which means that $\mathrm{H} 4$ reduction is lysosomeindependent. Next, we treated IMR90 cells with proteasome inhibitor MG132. Results showed that $\mathrm{H} 4$ was modestly restored in IMR90 cells treated with $\mathrm{H}_{2} \mathrm{O}_{2}$ (Fig. 3e). Similar result was seen in IMR90 cells with Ras overexpression or PRMT1 depletion (Fig. 3f and Supplementary Fig. 4c), suggesting a proteasome-mediated $\mathrm{H} 4$ degradation. The proteasome is able to recognize and promote the degradation of protein in an ubiquitin-dependent or independent manner. Ubiquitin proteasome system catalyzes the great majority (at least $80 \%$ ) of the protein degradation in mammalian cells. However, H4 ubiquitination was not increased under $\mathrm{H}_{2} \mathrm{O}_{2}$ treatment (Fig. 3g). Consistently, overexpression of Ras or depletion of PRMT1 did not change $\mathrm{H} 4$ ubiquitination level in IMR90 cells either (Fig. 3h and Supplementary Fig. 4d), which means that H4 
A

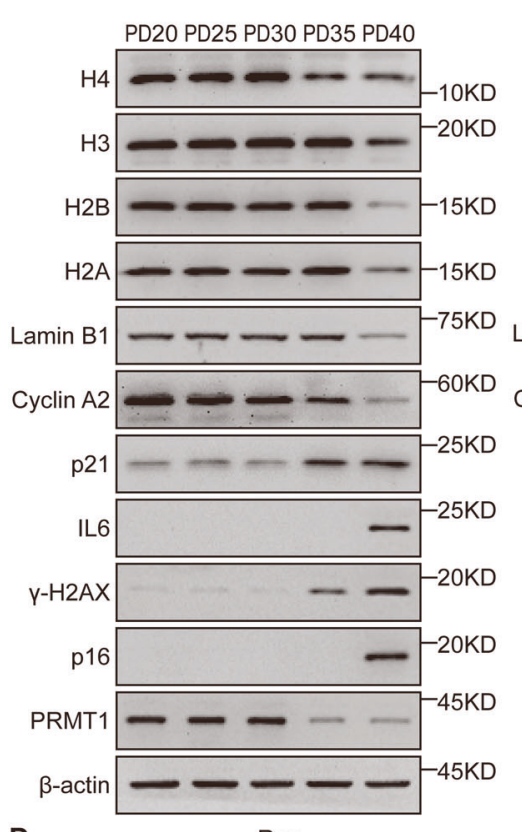

B

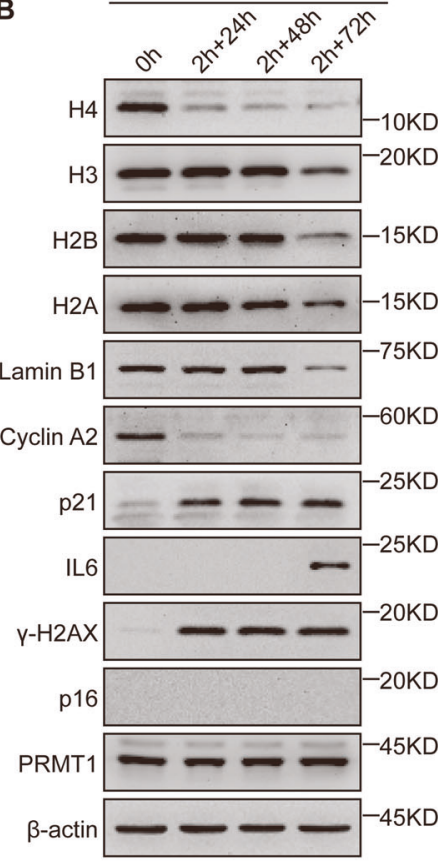

C

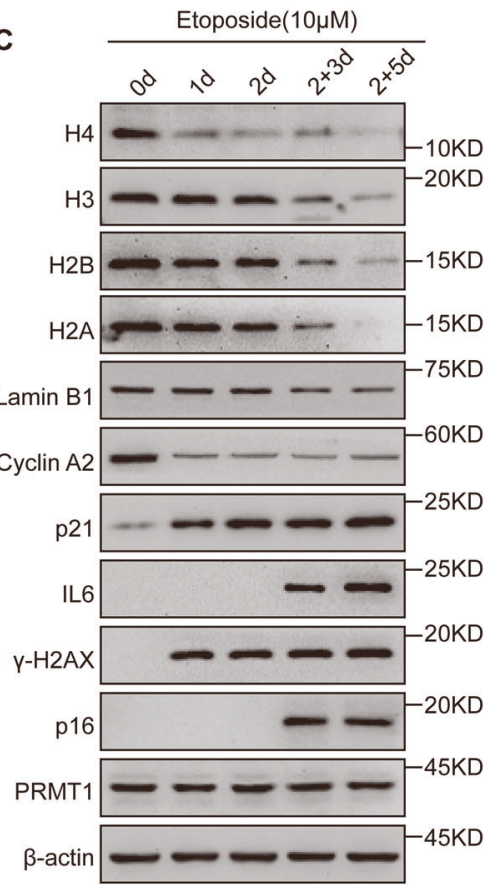

D

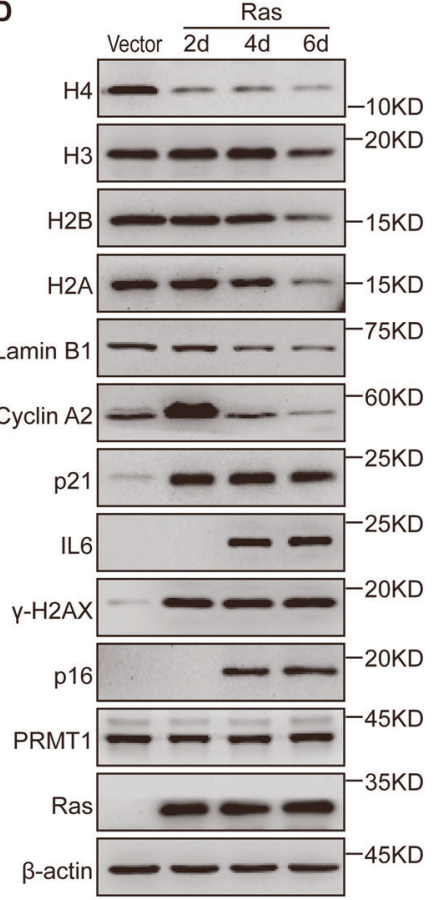

Fig. 2 Histone $\mathbf{H} 4$ prior decline in cellular senescence and skin aging in vivo. The level of PRMT1, Cyclin A2, Lamin B1, p21, $\gamma$ H2AX, IL6, p16, H2A, H2B, H3, and H4 was detected by western blotting in IMR90 cells of replicative senescence (a), oxidative stress

reduction is ubiquitin independent. In addition to ubiquitindependent protein degradation pathways, proteasome activator PA200 can form an $11 \mathrm{~S}$ regulatory particle to activate the $20 \mathrm{~S}$ proteasome. A previous study reported that PA200 specifically catalyzed the acetylation-dependent, but not poly-ubiquitination-dependent degradation of the core
$\left(\mathrm{H}_{2} \mathrm{O}_{2}\right)$ (b), DNA damage (Etoposide) (c) and oncogene (Ras) (d) induced cellular senescence at indicated time points. e Immunohistochemistry for core histones in paraffin sections of normal human skin, Scale bars: $100 \mu \mathrm{m}$.

histones during DNA damage repair and spermatogenesis [10]. This prompted us to investigate whether histone H4 degradation is mediated by PA200. Using coimmunoprecipitation assay, we did find that the interaction between PA200 and $\mathrm{H} 4$ was significantly increased under $\mathrm{H}_{2} \mathrm{O}_{2}$ treatment, Ras overexpression or PRMT1 

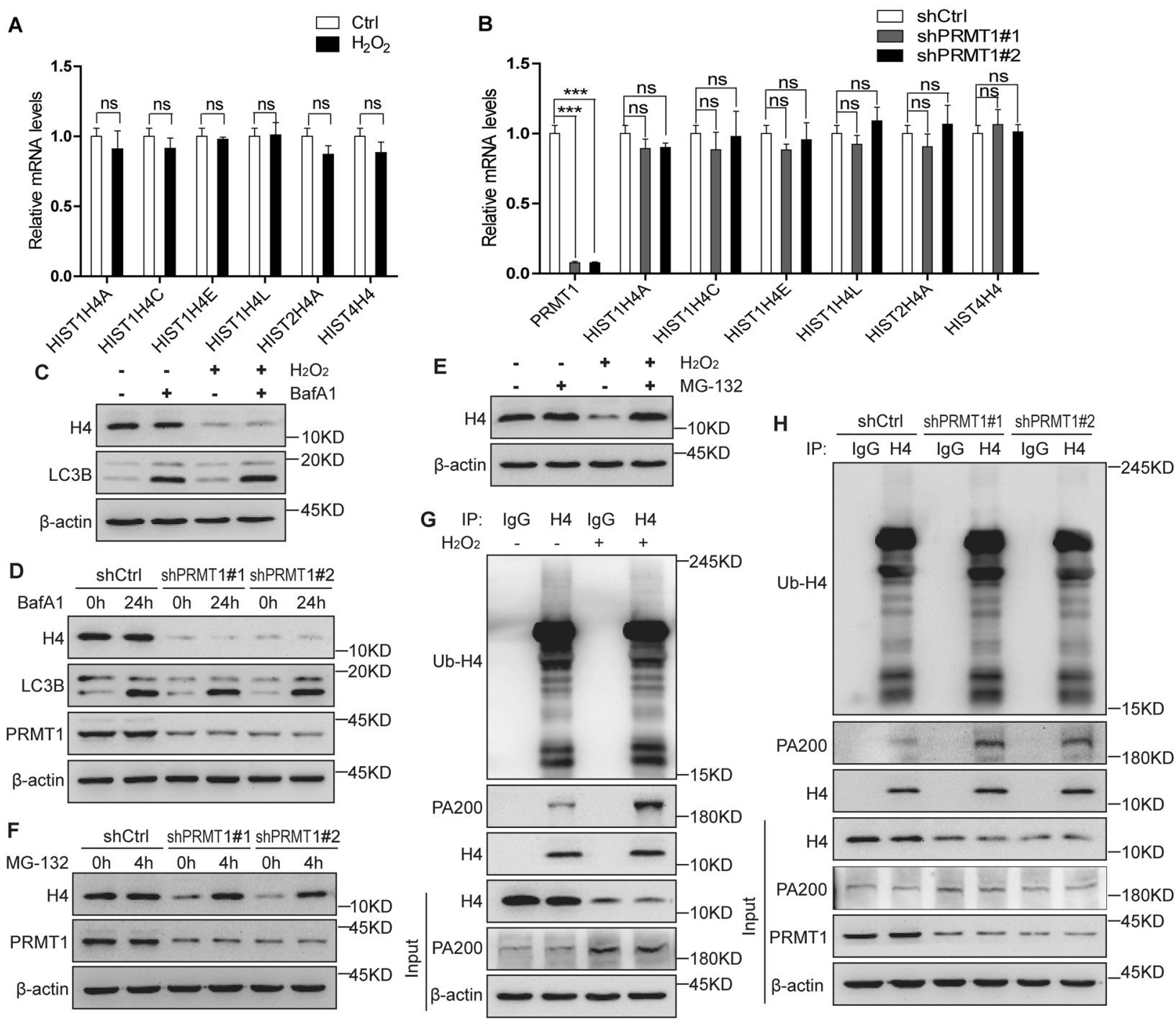

Fig. 3 PA200 is required for degradation of histone H4. IMR90 cells were treated with $\mathrm{H}_{2} \mathrm{O}_{2}$ for $2 \mathrm{~h}$ and then cultured with fresh complete medium for $24 \mathrm{~h}, \mathrm{H} 4 \mathrm{mRNA}$ level was assessed by qPCR (a), added Bafilomycin A1 (100 nM) for 0 or $24 \mathrm{~h}$, expression of $\mathrm{H} 4$ was detected by western blotting, LC3B was used as a positive control (c), added MG132 $(20 \mu \mathrm{M})$ for 0 or $4 \mathrm{~h}$, expression of $\mathrm{H} 4$ was detected by western blotting (e), endogenous H4-associated ubiquitination and PA200 after co-immunoprecipitation assay with anti-H4 antibody was detected by western blotting (g). IMR90 cells were infected with

depletion (Fig. 3g, h and Supplementary Fig. 4d), implicating that depletion of PRMT1, overexpressed Ras or $\mathrm{H}_{2} \mathrm{O}_{2}$ treatment promotes $\mathrm{H} 4$ degradation through increasing the interaction between PA200 and $\mathrm{H} 4$.

\section{The PRMT1-mediated H4R3me2as maintains histone H4 stability}

Having shown that depletion of PRMT1 triggers $\mathrm{H} 4$ degradation, we ask what roles of H4R3me2as may play in maintaining $\mathrm{H} 4$ stability. We first detected changes of control shRNA (shCtrl) or PRMT1 shRNA (shPRMT1\#1 or \#2) for 4 days, H4 mRNA level was assessed by qPCR (b), added Bafilomycin A1 (100 nM) for 0 or $24 \mathrm{~h}$, expression of $\mathrm{H} 4$ was detected by western blotting, LC3B was used as a positive control (d), added MG132 $(20 \mu \mathrm{M})$ for 0 or $4 \mathrm{~h}$, expression of $\mathrm{H} 4$ was detected by western blotting (f), endogenous H4-associated ubiquitination and PA200 after co-immunoprecipitation assay with anti-H4 antibody was detected by western blotting (h). Each experiment was repeated at least three times. Error bars, mean $\pm \mathrm{SD}$, ns no significant, $* * * P<0.001$.

$\mathrm{H} 4 \mathrm{R} 3 \mathrm{me} 2$ as and $\mathrm{H} 4$ in IMR90 cells treated with $\mathrm{H}_{2} \mathrm{O}_{2}$. Results showed that $\mathrm{H}_{2} \mathrm{O}_{2}$ induced $\mathrm{H} 4$ degradation from $21 \mathrm{~h}$, while H4R3me2as declined from $12 \mathrm{~h}$ after treatment (Fig. 4a). We then knocked down PRMT1 in IMR90 cells, and we found that H4R3me2as was reduced from the 2nd day and $\mathrm{H} 4$ begun to degrade from the 4th day (Fig. 4b). Next, we constructed lentiviral vectors containing shRNAs targeting the 3'UTR of PRMT1 to knockdown the endogenous PRMT1 in IMR90 cells. We transfected PRMT1 wild-type or PRMT1 enzymatic activity mutant (PRMT1G80R) into IMR90 cells with endogenous PRMT1 
A
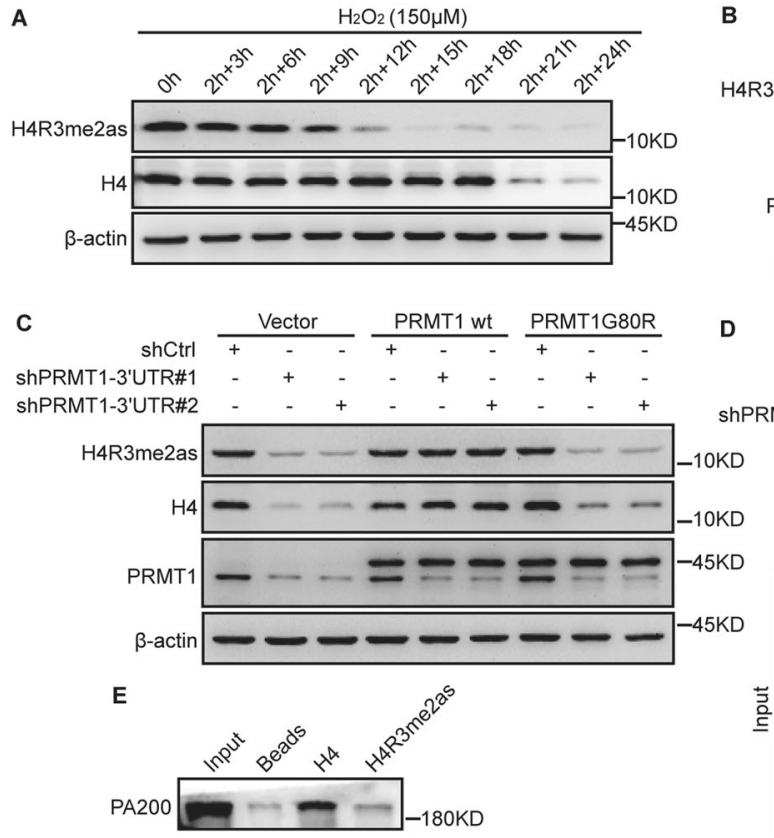

Fig. 4 Reduction of H4R3me2as was required for efficient histone H4 degradation. a IMR90 cells were treated with $\mathrm{H}_{2} \mathrm{O}_{2}$ for $2 \mathrm{~h}$ and then cultured with fresh complete medium for indicated time points, $\mathrm{H} 4$ and H4R3me2as levels were detected by western blotting. b IMR90 cells were infected with control shRNA (shCtrl) or PRMT1 shRNA (shPRMT1\#1 or \#2) for 2, 4, and 6 days, H4 and H4R3me2as levels were detected by western blotting. c IMR90 cells were infected with either $3 \times$ Flag-PRMT1 or $3 \times$ Flag-PRMT1mut; after 2 days cells were infected with control shRNA (shCtrl) or PRMT13'UTR shRNA (shPRMT1-3'UTR\#1 or \#2) for 4 days, H4, PRMT1,

knockdown, respectively. Western blots showed that restoration of PRMT1 expression in IMR90-shPRMT13'UTR cells inhibited H4 degradation (Fig. 4c), suggesting that H4R3me2as maintains H4 stability. Subsequently, we discovered that PRMT1 depletion increased association of PA200 with H4, which was alleviated by reconstituted expression of PRMT1 wild-type but not by PRMT1G80R (Fig. 4d). To further test whether H4R3me2as suppresses PA200 interaction with $\mathrm{H} 4$, we incubated streptavidin agarose beads, containing immobilized unmodified or asymmetric dimethylated biotinylated peptides of $\mathrm{H} 4$, with IMR90 cell lysates, and the results demonstrated that PA200 bound more efficiently to $\mathrm{H} 4$ peptides than asymmetric dimethylated at R3 of $\mathrm{H} 4$ peptides (Fig. 4e). Thus, the PRMT1-mediated H4R3me2as maintains histone H4 stability.

\section{Histone $\mathrm{H} 4$ degradation regulates the expression of the cell cycle inhibitor genes, SASP-related genes, and anti-apoptotic genes}

The core histones, $\mathrm{H} 2 \mathrm{~A}, \mathrm{H} 2 \mathrm{~B}, \mathrm{H} 3$, and $\mathrm{H} 4$, form an octamer to pack DNA into the nucleosome. We next wondered whether $\mathrm{H} 4$ degradation promoted nucleosome decomposition to cause a decrease in nucleosome occupancy. We performed MNase digestion to assess global changes in nucleosome abundance. The results showed that MNase digestion of chromatin resulted in attenuated amounts of the lower molecular weight DNA fragments, especially the 1st, 2nd, and 3rd smallest bands in $\mathrm{H}_{2} \mathrm{O}_{2}$ treatment or PRMT1 knockdown IMR90 cells (Fig. 5a, b). These reduced lower molecular weight DNA fragments reflect the nucleosome decomposition and nucleosome occupancy decrease caused by $\mathrm{H} 4$ degradation. It has also been demonstrated that nucleosome occupancy decrease leads to global upregulation of gene expression related with aging $[4,5]$. To gain a better understanding of the gene expression pattern mediated by $\mathrm{H} 4$ degradation, we performed RNA-seq in $\mathrm{H}_{2} \mathrm{O}_{2}$-treated IMR90 cells, and found remarkable changes of global gene expression in $\mathrm{H}_{2} \mathrm{O}_{2}$-treated cells compared with that of the control cells (Fig. 5c, d and Supplementary Table 1). Among which, we focused on the expression of cell cycle inhibitor genes, SASP-related genes, and anti-apoptotic genes that play important roles during senescence. Moreover, the realtime qPCR results demonstrated that cell cycle inhibitor genes p21 and GADD45A, SASP-related genes FGF2, IL11, 
A

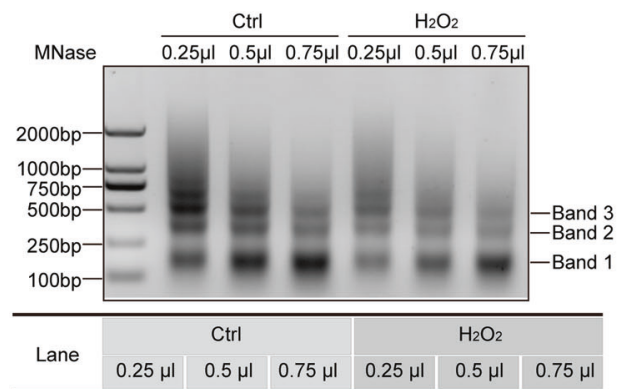

B

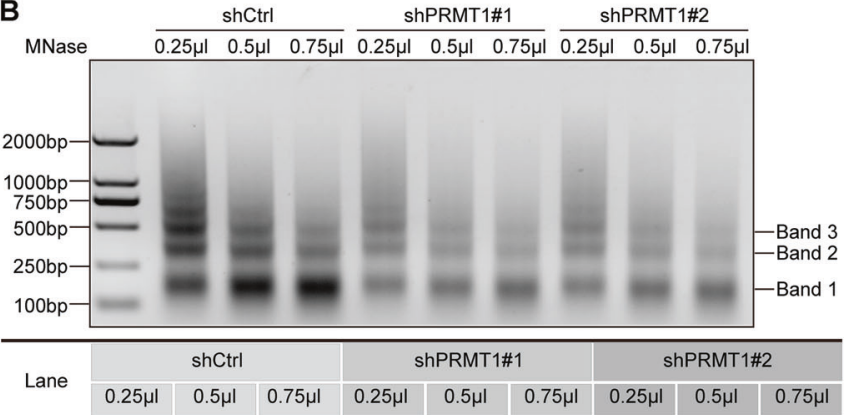

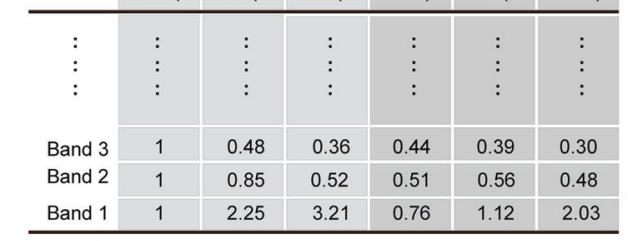
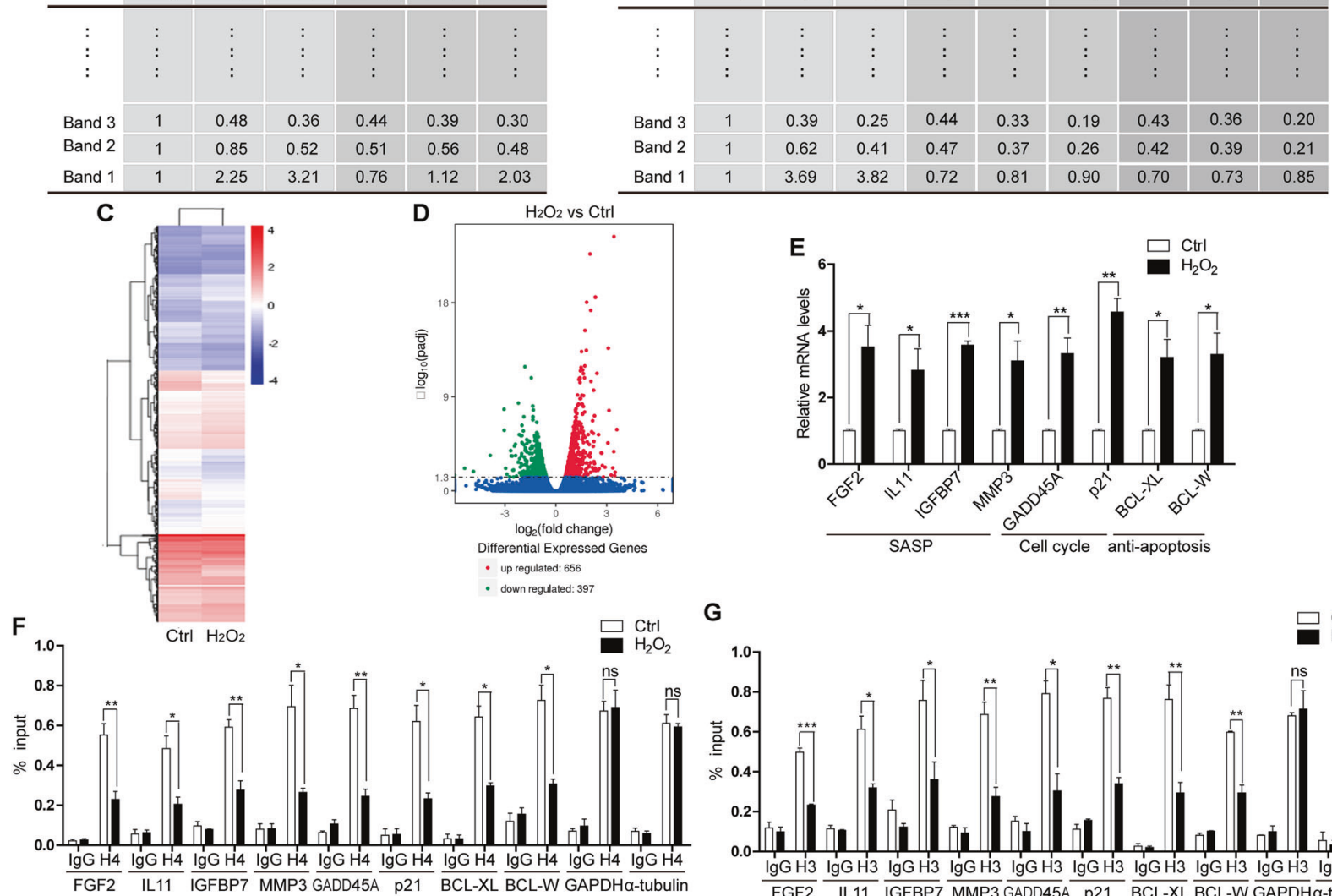

Fig. 5 Histone $\mathbf{H 4}$ degradation increased cell cycle inhibitor genes, SASP-related genes, and anti-apoptotic genes expression. a IMR90 cells were treated with $\mathrm{H}_{2} \mathrm{O}_{2}$ for $2 \mathrm{~h}$ and then cultured with fresh complete medium for $24 \mathrm{~h}$, nuclei were isolated and analyzed in a MNase assay using three different doses of MNase. The band intensities quantified using ImageJ. b IMR90 cells were infected with control shRNA (shCtrl) or PRMT1 shRNA (shPRMT1\#1 or \#2) for 4 days, nuclei were isolated and analyzed in a MNase assay using three different doses of MNase. The band intensities quantified using ImageJ. c Heat map showed gene expression changes of 1053 genes as determined by RNA-seq in $\mathrm{H}_{2} \mathrm{O}_{2}$ treated IMR90 cells relative to control cells, $P<0.01$. d Volcano Plot of 656 genes upregulated and

IGFBP7, and MMP3, anti-apoptotic genes BCL-XL and BCL-W exhibited a significant upregulation in $\mathrm{H}_{2} \mathrm{O}_{2}$ treatment or PRMT1 knockdown IMR90 cells (Fig. 5e and Supplementary Fig. 5a). Since H4 degradation can directly lead to nucleosome occupancy decrease, and is linked to transcriptional activation, we intended to determine whether histone H4 was lost at genes' promoter to active

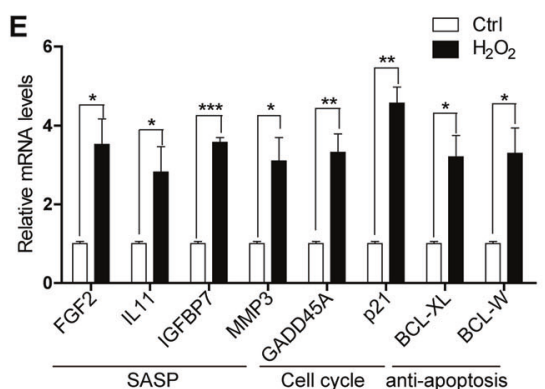

G

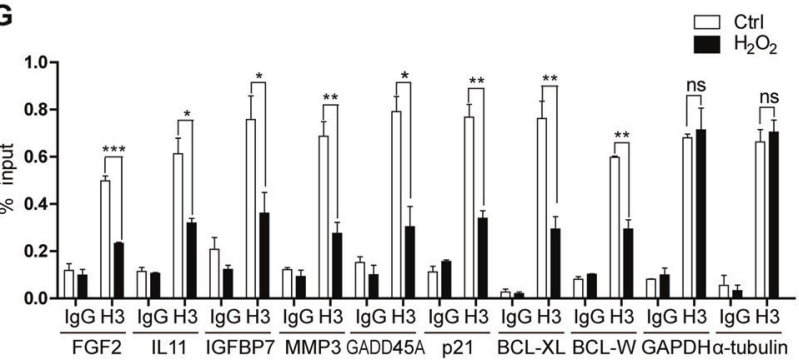

397 genes downregulated in $\mathrm{H}_{2} \mathrm{O}_{2}$ treated IMR90 cells compared with the control cells. e IMR90 cells were treated with $\mathrm{H}_{2} \mathrm{O}_{2}$ for $2 \mathrm{~h}$ and then cultured with fresh complete medium for $48 \mathrm{~h}$, cell cycle inhibitor genes, SASP-related genes, and anti-apoptotic genes mRNA levels were assessed by qPCR. IMR90 cells were treated with $\mathrm{H}_{2} \mathrm{O}_{2}$ for $2 \mathrm{~h}$ and then cultured with fresh complete medium for $24 \mathrm{~h}$, qChIP experiments for $\mathrm{H} 4$ (f) and $\mathrm{H} 3(\mathbf{g})$ to measure the levels of $\mathrm{H} 4$ and $\mathrm{H} 3$ at the promoter of cell cycle inhibitor genes, SASP-related genes, antiapoptotic genes, and house-keeping genes. Each experiment was repeated at least three times. Error bars, mean $\pm \mathrm{SD}, * P<0.05$, $* * P<$ $0.01, * * * P<0.001$.

transcription. qChIP assay also revealed a significant reduction in the enrichment of $\mathrm{H} 4$ and $\mathrm{H} 3$ at cell cycle inhibitor genes p21 and GADD45A, SASP-related genes FGF2, IL11, IGFBP7, and MMP3, anti-apoptotic genes BCL-XL and BCL-W in $\mathrm{H}_{2} \mathrm{O}_{2}$ treatment and PRMT1 knockdown IMR90 cells, while the enrichment of $\mathrm{H} 4$ and $\mathrm{H} 3$ at house-keeping genes GAPDH and $\alpha$-tubulin promoter 


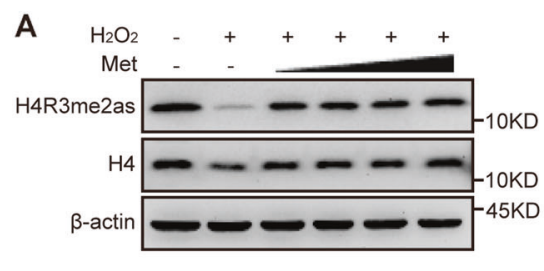

D

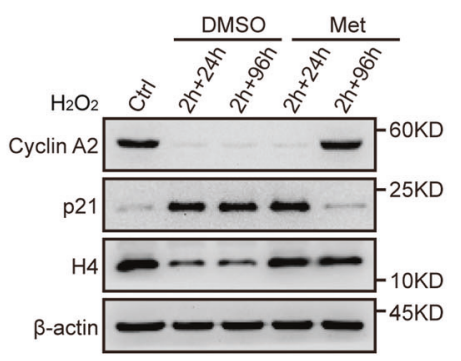

G
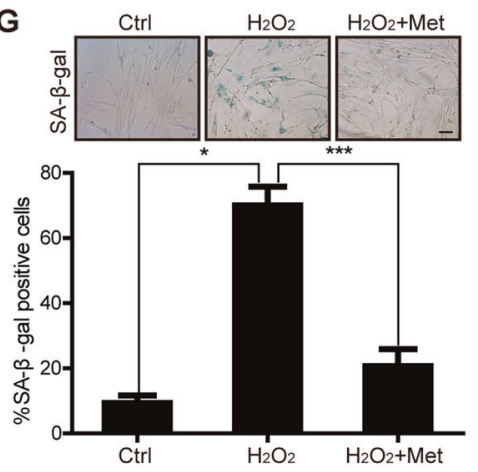

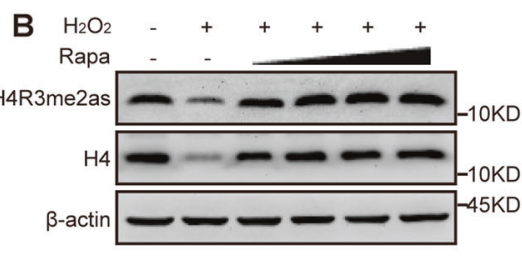

E
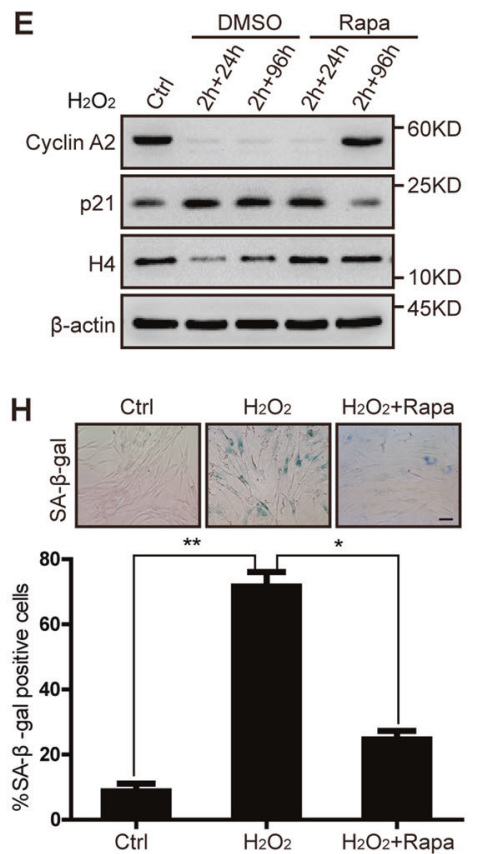

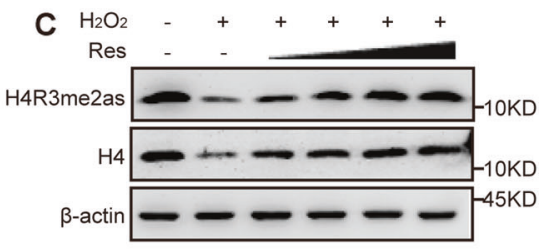

$\mathbf{F}$
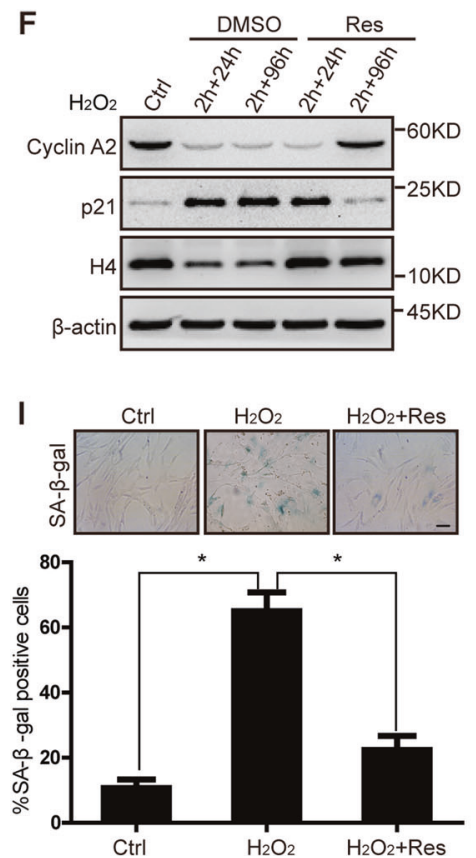

Fig. 6 Metformin (Met), Rapamycin (Rapa) and Resveratrol (Res) treatment restored $\mathrm{H} 4$ expression and alleviated cellular senescence by $\mathrm{H}_{2} \mathrm{O}_{2}$ treatment. IMR90 cells were treated with $\mathrm{H}_{2} \mathrm{O}_{2}$ for $2 \mathrm{~h}$ and then cultured with fresh complete medium added different concentrations of Met $(100 \mu \mathrm{M}, 200 \mu \mathrm{M} 500 \mu \mathrm{M}$ and $1 \mathrm{mM})$ (a), Rapa $(50 \mathrm{nM}, 100 \mathrm{nM}, 200 \mathrm{nM}$ and $500 \mathrm{nM})(\mathbf{b})$ or Res $(1 \mu \mathrm{M}, 2 \mu \mathrm{M}, 5 \mu \mathrm{M}$, and $10 \mu \mathrm{M})(\mathbf{c})$ for $24 \mathrm{~h}, \mathrm{H} 4$ and $\mathrm{H} 4 \mathrm{R} 3 m e 2$ as levels were detected by western blotting. IMR90 cells were treated with $\mathrm{H}_{2} \mathrm{O}_{2}$ for $2 \mathrm{~h}$ and then cultured with fresh complete medium added $100 \mu \mathrm{M}$ Met (d), $50 \mathrm{nM}$
Rapa (e) and $1 \mu \mathrm{M}$ Res (f) for $24 \mathrm{~h}$ and $96 \mathrm{~h}$, expression of $\mathrm{H} 4$, Cyclin A2 and p21 was detected by western blotting. IMR90 cells were treated with $\mathrm{H}_{2} \mathrm{O}_{2}$ for $2 \mathrm{~h}$ and then cultured with fresh complete medium added $100 \mu \mathrm{M}$ Met (g), $50 \mathrm{nM}$ Rapa (h), and $1 \mu \mathrm{M}$ Res (i) for $96 \mathrm{~h}$, cells were subjected to SA- $\beta$-gal staining. Top panel showed the representative images. The percentage of SA- $\beta$-gal positive cells was calculated (lower). Scale bars: $100 \mu \mathrm{m}$. Each experiment was repeated at least three times. Error bars, mean $\pm \mathrm{SD}, * P<0.05, * * P<0.01$, $* * * P<0.001$. regions didn't change (Fig. 5g, h and Supplementary Fig. 5b, c). These results indicate that $\mathrm{H} 4$ and $\mathrm{H} 3$ enrichment was decreased at the promoters of cell cycle inhibitor genes, SASP-related genes, and anti-apoptotic genes. Based on these results, we speculated that the degradation of $\mathrm{H} 4$ occurred at senescence-associated gene regions, further promoted nucleosome decomposition and upregulated senescence-associated gene transcription.

\section{Histone $\mathrm{H} 4$ as a potential anti-aging drug screening marker}

The above data have provided evidence that $\mathrm{H} 4$ degradation is an early senescence-associated indicator. An immediate intriguing application of this phenomenon is that $\mathrm{H} 4$ might be used as an anti-aging drug screening target. To substantiate this assumption, we tested 3 well-informed antiaging drugs metformin, rapamycin, and resveratrol in
IMR90 cells under $\mathrm{H}_{2} \mathrm{O}_{2}$ treatment [18-20]. The results showed that $\mathrm{H} 4$ and $\mathrm{H} 4 \mathrm{R} 3 \mathrm{me} 2$ as were all distinctly restored by all three anti-aging drugs at $24 \mathrm{~h}$ (Fig. 6a-c). Indeed, the three drugs all delayed $\mathrm{H}_{2} \mathrm{O}_{2}$-induced IMR90 cell senescence characterized by the reduced proportion of SA- $\beta$-gal positive cells, upregulation of Cyclin A2 and reduction of p21 at $96 \mathrm{~h}$. Compared with SA- $\beta$-gal, Cyclin A2 and p21, $\mathrm{H} 4$ was significantly increased at $24 \mathrm{~h}$ after anti-aging drug treatment (Fig. 6d-i). Similar results were found in IMR90Ras cells treated with metformin (Supplementary Fig. 6). These results support the notion that histone $\mathrm{H} 4$ may be a potential anti-aging drug screening marker.

\section{Discussion}

In this study, we unveil a novel regulatory mechanism of PRMT1-mediated H4R3me2as in cellular senescence 
Fig. 7 A proposed working model for histone $\mathrm{H} 4$ degradation in regulation of cellular senescence. In normal growing cells, PRMT1 mediated H4R3me2as maintains histone H4 stability and cell proliferation. When cells are exposed to the senescence signals, such as oxidative stress, DNA damage or hyperoncogenic signaling pressure, PRMT1 mediated H4R3me2as reduction leads to $\mathrm{H} 4$ degradation and further nucleosome decomposition, results in nucleosome occupancy decrease and activates senescence-associated genes transcription, thus promotes cellular senescence.

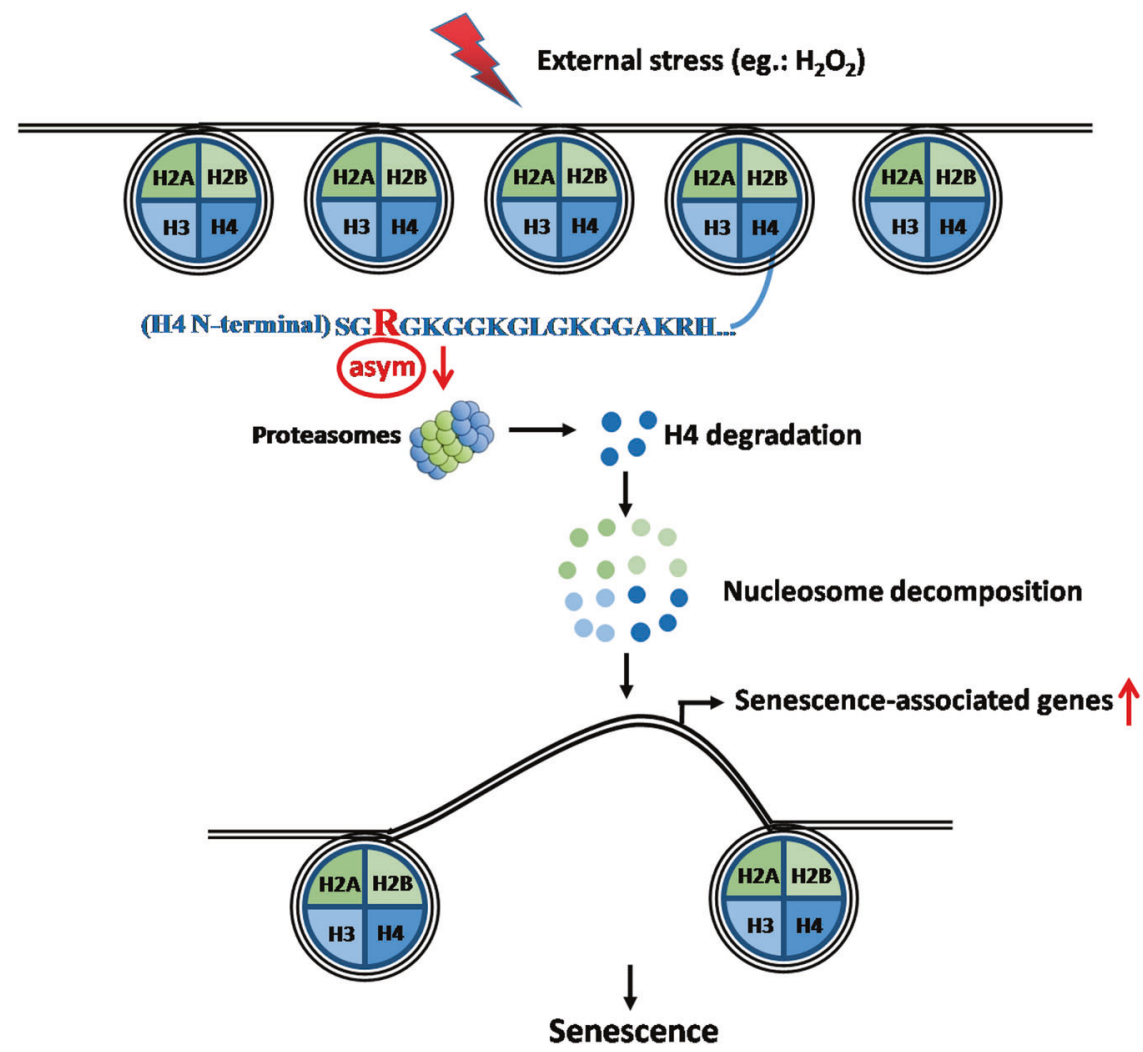

through affecting $\mathrm{H} 4$ stability. We propose a model in which external stress (e.g. $\mathrm{H}_{2} \mathrm{O}_{2}$ ) leads to the reduction of H4R3me2as, which enhances PA200 binding to $\mathrm{H} 4$ to catalyze the poly-ubiquitin-independent degradation of $\mathrm{H} 4$. $\mathrm{H} 4$ degradation further promotes the other 3 core histones disintegration, resulting in nucleosome occupancy decrease and activation of senescence-associated gene transcription, consequently resulting in cellular senescence (Fig. 7).

Evidence from this study demonstrated that $\mathrm{H} 4$ decreased earlier than the other 3 histones in all the senescence models tested (Fig. 2a-d). Our data are in support of the view that $\mathrm{H} 4$ reduction might be an early biomarker of cellular senescence. To validate this, we ectopically expressed $\mathrm{H} 4$ in IMR90 cells treated with $\mathrm{H}_{2} \mathrm{O}_{2}$ or overexpressed Ras to evaluate whether rescued $\mathrm{H} 4$ could delay senescence. However, ectopic $\mathrm{H} 4$ was also degraded under $\mathrm{H}_{2} \mathrm{O}_{2^{-}}$or Ras-induced senescence (Supplementary Fig. 7a, b). Consistently, the senescence phenotype was not rescued (Supplementary Fig. 7a-d). Together, these data suggest that ectopic expression of $\mathrm{H} 4$ has little impact on cellular senescence because ectopic $\mathrm{H} 4$ was also degraded by $\mathrm{H}_{2} \mathrm{O}_{2}$ or Ras. In addition, overexpression of PRMT1 did not inhibit $\mathrm{H} 4$ degradation induced by $\mathrm{H}_{2} \mathrm{O}_{2}$ or Ras (Supplementary Fig. 8a, b). Also, overexpression of PRMT1 did not rescue $\mathrm{H}_{2} \mathrm{O}_{2}$ - or Ras-induced senescence (Supplementary Fig. 8c, d). In these cases, we noticed that the level of global asymmetric methylation was decreased even in cells ectopically expressed PRMT1 (Supplementary Fig. 7a, b and Supplementary Fig. 8a, b), indicating that ectopic PRMT1 was inhibited by $\mathrm{H}_{2} \mathrm{O}_{2}$ or Ras. In line with our finding, it has also been reported that PRMT1 is a redoxresponsive enzyme. Oxidation at the two cysteine residues of PRMT1 to sulfenic acid potentially destabilizes dimerization, leading to diminished methyltransferase activity [21]. Based on the existing reports as well as our results, we hypothesized that PRMT1 enzyme activity was inhibited by $\mathrm{H}_{2} \mathrm{O}_{2}$ or other stimuli such as Ras. That is why the overexpressed H4 or PRMT1 is unable to reverse senescent phenotypes. However, the ectopically overexpressed wildtype PRMT1, but not the PRMT1 enzymatic activity mutant (PRMT1G80R), inhibits H4 degradation under knockdown the 3'UTR of PRMT1 (Fig. 4c). These results further confirmed our speculation that to response the rapid stimulus, the enzyme activity of PRMT1 is inhibited during premature senescence.

Cellular senescence is induced by a wide variety of conditions. Senescent cells display a number of characteristics that allow their identification both in vitro and in vivo. The currently well-accepted senescence biomarkers are as follows: alarge and flattened morphology [22]; accumulation of lysosomal content [23]; presence of senescence-associated heterochromatin foci (SAHF) [24]; upregulation of cell cycle inhibitor genes [25]; expression of a secretory phenotype [26]; and positive staining for senescence-associated 
$\beta$-galactosidase (SA- $\beta$-gal) [27]. To date, none of the characterized markers documented is $100 \%$ specific or unique to senescence. For example, the most commonly used biomarker of senescence, SA- $\beta$-gal, is not suitable for use in formalin-fixed paraffin-embedded clinical samples and might not be specific to senescence in vivo, making it unsuitable as a marker for clinical applications [28]. SASP is also well accepted as a characteristic of senescence. SASP has roles in the pathophysiological activity of senescent cells, but it is too unspecific and heterogeneous to be used as an unequivocal marker for senescence [29, 30], which are implicated in several biological processes, such as cancer progression [29]. Besides, some senescent cells do not secrete the typical range of SASP cytokines such as embryonic senescence [31]. The senescence phenotype is often characterized by the activation of a chronic DNA damage response (DDR). Induction of $\gamma$ $\mathrm{H} 2 \mathrm{AX}$ nuclear foci is also commonly used as a marker of senescence [32]. However, DDR is also activated by a variety of DNA-damaging stimuli that do not lead cells into a senescent state, such as DNA repair and apoptosis [33]. Moreover, not all senescence programs are a consequence of DDRs. For cell cycle-related senescence markers, p16 is often used as a unique and specific marker [25]. However, p16 expression was not upregulated in some cellular senescence models, and our results revealed that the expression of p16 did not change under $\mathrm{H}_{2} \mathrm{O}_{2}$-induced cellular senescence (Fig. 2b). Above all, a major barrier to the development of senescence antagonism is the lack of a 'gold standard' marker of senescence to enable efficient detection and measurement in vivo and in vitro. Here we provide a novel senescence biomarker, histone $\mathrm{H} 4$, whose decline is earlier than the upregulation of p16 during senescence (Fig. 2a, c, d). Furthermore, the decline of $\mathrm{H} 4$ is also much earlier than the downregulation of Lamin B1 (Fig. 2a-d). In addition, $\mathrm{H} 4$ level is not decreased under apoptosis or quiescent condition (Supplementary Fig. 3). More importantly, $\mathrm{H} 4$ level is also reduced prior to the other 3 core histones during human skin aging (Fig. 2e), which suggests that histone $\mathrm{H} 4$ might be an early biomarker for cellular senescence both in vitro and in vivo.

This study also uncovers a role of the PRMT1-mediated H4R3me2as in regulating H4 stability. As H4R3 is also a substrate for PRMT5, which catalyze symmetric dimethylation of histone H4R3 (H4R3me2s) [34], we suspected whether a switch between PRMT5-mediated H4R3me2s and PRMT1-mediated H4R3me2as in coordination to maintain $\mathrm{H} 4$ stability. However, H4R3me2s level did not show remarkable change before $\mathrm{H} 4$ degradation under $\mathrm{H}_{2} \mathrm{O}_{2}$ treatment (Supplementary Fig. 9). Besides arginine methylation, a recent report shows that PA200 mediates proteasomal degradation of core histones through binding to acetylated core histones during DNA repair and spermatogenesis [10]. Moreover, reduction of $\mathrm{H} 4 \mathrm{~N}$-terminal K5/8/12acetylation induces H4R3me2as deposition and rDNA silencing [35]. Based on the previous reports, we assessed the potential links between $\mathrm{H} 4$ acetylation and H4R3me2as. In contrast to these results, our results revealed that $\mathrm{H} 4$ acetylation was decreased prior to $\mathrm{H} 4 \mathrm{R} 3$ me2as under $\mathrm{H}_{2} \mathrm{O}_{2}$ treatment (Supplementary Fig. 9), which suggests additional posttranslational modifications of $\mathrm{H} 4$ may also be required to maintain $\mathrm{H} 4$ stability. Beside the crosstalk between $\mathrm{H} 4$ lysine acetylation and H4R3me2as, histone $\mathrm{H} 4$ serine 1 residue phosphorylation ( $\mathrm{H} 4 \mathrm{~S} 1 \mathrm{ph})$ has also been reported to be negatively correlated with H4R3me2as during lung cancer progression [36]. Whether H4S1ph mediates crosstalk with H4R3me2as in regulating $\mathrm{H} 4$ stability needs further investigation.

In addition, we found that the anti-aging drugs, such as metformin, rapamycin, and resveratrol, all restored $\mathrm{H} 4$ expression at $24 \mathrm{~h}$ (Fig. 6a-c), much earlier than the wellknown senescence markers SA- $\beta$-gal, suggesting that these drugs represses $\mathrm{H} 4$ degradation. For the mechanism that the anti-aging drugs repress $\mathrm{H} 4$ degradation, we have speculation as followed. First, the anti-aging drugs may enhance PRMT1 enzymatic activity and increase H4R3me2as level, which inhibit the interaction between PA200 and H4. Moreover, it has been reported that rapamycin binds to specific grooves on the $\alpha$ face region and interferes the binding of PA200-proteasome activator to the $20 \mathrm{~S}$ proteasome, which is essential for processing of poly-ubiquitinindependent substrates [37]. Whether metformin and resveratrol inhibit histone $\mathrm{H} 4$ degradation through regulating PA200-proteasome requires further study.

In summary, the present study unveils a novel function of the PRMT1-mediated H4R3me2as in modulation of cellular senescence via regulating $\mathrm{H} 4$ stability. Our findings also points to the value of histone $\mathrm{H} 4$ as an early senescence indicator and a potential anti-aging drug screening marker.

\section{Materials and methods}

\section{Cell cultures and treatment}

All the cell lines (IMR90, CRL-1474, HEK-293T) were obtained from the American Type Culture Collection and cultured in Dulbecco's modified Eagle's medium (DMEM) supplemented with $10 \%$ (vol/vol) fetal bovine serum, and penicillin-streptomycin. IMR90 and CRL-1474 cultured at $37{ }^{\circ} \mathrm{C}, 5 \% \mathrm{CO}_{2}$, and $5 \% \mathrm{O}_{2}$. HEK-293T cultured at $37{ }^{\circ} \mathrm{C}$, $5 \% \mathrm{CO}_{2}$. Cells were tested by a MycoBlue Mycoplasma Detector (Vazyme Biotech, Nanjing, China) to exclude Mycoplasma contamination before experiments.

For $\mathrm{H}_{2} \mathrm{O}_{2}$-induced premature senescence, the growing IMR90 cells were seed at a cell density of $1.5 \times 10^{6}$ in $100 \mathrm{~mm}$ dishes. On second day after seeding, the cells were incubated with the culture medium containing $150 \mu \mathrm{M}$ 
concentrations of $\mathrm{H}_{2} \mathrm{O}_{2}$ for $2 \mathrm{~h}$. After $\mathrm{H}_{2} \mathrm{O}_{2}$ treatment, the cells were washed twice with PBS and cultured with fresh complete medium for indicated times.

\section{RNA extraction, RT-PCR and real-time PCR analysis}

Total RNA was extracted from cells using the Trizol reagent (Takara, Dalian, China) following manufacturer's instructions. The cDNA was generated using the Reverse Transcription System (Promega). Real-time PCR was carried out on a Roche LightCycler 480 using SYBR Green Real-time PCR Master Mix (Roche). The $\beta$-actin was used as an internal control. The sequences of PCR primers were listed in Supplementary Table 2.

\section{RNA-seq}

Total RNA samples were isolated and prepared at the Novogene, Beijing. Facility for poly A library construction and sequencing on IlluminaHiSeq 2000. All raw RNAsequencing reads were mapped to the human genome (hg19) with TopHat coupled with Bowtie 2 with default parameters. Transcriptomes were assembled and fragments per kilo-base per million reads for each gene were computed with Cufflinks. Differentially expressed genes were identified using $\log 2$ fold change of fragments per kilo-base per million read values for all samples in pair-wise combinations. Raw and processed RNA-seq data have been deposited in the Gene Expression Omnibus GSE134088.

\section{Plasmids and viral infection}

The following vectors were used in this study: pCDHCMV-3×Flag-RASG12V, pCDH-CMV-3×Flag-PRMT1, pCDH-CMV-3×Flag-PRMT1G80R, pCDH-CMV-H4, The control, PRMT1 and PRMT1-3'UTR short hairpin RNA plasmids were constructed in the pLKO.1-puro backbone. The lentivirus packaging vectors used were psPAX2 and pMD2.G. Generation of lentivirus in $293 \mathrm{~T}$ cells and transfection of lentiviral constructs into recipient cell lines were performed following manufacturer's instructions (Invitrogen). The sequences of shRNAs were described in Supplementary Table 3.

\section{Western blotting}

Cells were lysed in 1×Laemmli sample buffer and 5-20 $\mu \mathrm{g}$ of protein was resolved by SDS-PAGE followed by transfer onto PVDF membrane and probing with antibodies. Antibodies used in this study are as follows: H2A (Cell Signaling Technology \#12349), H2B (Abcam ab1790), H3 (Abcam ab1791), H4 (Abcam ab10158), $\beta$-actin (SigmaAldrich A1978), LC3B (Cell Signaling Technology \#3868),
PA200 (Abcam ab181128), PRMT1 (Millipore \#07-404), IL6 (Immunoway YT5348), Ras (Millipore \#05-1027), Ki67 (GeneTex GTX16667), H4R3me2as (Active Motif 39705), p16 (Immunoway YT5664), Anti-acetyl-Histone H4 (Millipore \#06-866), H4R3me2s (Active Motif 61187), Ubiquitin (Cell Signaling Technology \#3933), $\gamma$-H2AX (Cell Signaling Technology \#9718), Lamin B1 (Abcam ab16048).

\section{Immunofluorescence}

Cells were seeded on glass cover-slips in 12-well plates, left overnight before the treatment. Cells were fixed in $1 \%$ formaldehyde in culture medium for $10 \mathrm{~min}$ at $37^{\circ} \mathrm{C}$ and permeabilized with $0.2 \%$ Triton $\mathrm{X}-100$ in PBS for $10 \mathrm{~min}$ at room temperature. Cells were washed twice in PBS and blocked for $1 \mathrm{~h}$ with $5 \%$ BSA in PBS and then incubated with primary antibodies at $4{ }^{\circ} \mathrm{C}$ overnight, washed three times in PBS and incubated with secondary antibodies for $1 \mathrm{~h}$ at room temperature. Cell nuclei were counterstained with a $500 \mathrm{nM}$ concentration of DAPI (Sigma). Photographs were taken using a confocal microscope (OLYMPUS).

\section{Micrococcal Nuclease (MNase) assay}

MNase assay was performed as described [38]. Briefly, $5 \times$ $10^{6}$ cells were resuspended in $300 \mu \mathrm{l}$ of HNB (15mMTris$\mathrm{HCl}, \mathrm{pH} 7.6,0.5 \mathrm{M}$ sucrose, $60 \mathrm{mM} \mathrm{KCl}, 0.25 \mathrm{mM}$ EDTA, $0.125 \mathrm{mM}$ EGTA, $0.5 \%$ Triton X-100, $1 \mathrm{mM}$ DTT, $0.5 \mathrm{mM}$ PMSF). After 20 min incubation on ice, nuclei were isolated by centrifugation at $3000 \mathrm{rpm}$ for $5 \mathrm{~min}$. Nuclei were gently resuspended in $50 \mu \mathrm{l}$ of nuclear buffer $(20 \mathrm{mM}$ Tris- $\mathrm{HCl}, \mathrm{pH}$ 7.6, $70 \mathrm{mM} \mathrm{NaCl}, 20 \mathrm{mM} \mathrm{KCl}, 5 \mathrm{mM} \mathrm{MgCl} 2$, and $3 \mathrm{mM}$ $\mathrm{CaCl}_{2}$ ). Nuclei suspension was incubated with $0.25 \mu \mathrm{l}$, $0.5 \mu \mathrm{l}, 0.75 \mu \mathrm{l}$ of micrococcal nuclease (Cell Signaling Technology \#10011) at $37^{\circ} \mathrm{C}$ for $10 \mathrm{~min}$. The digestion was terminated by addition of EDTA and EGTA to a $5 \mathrm{mM}$ final concentration each. The nuclear pellets were collected by centrifugation at $5000 \mathrm{rpm}$ for $5 \mathrm{~min}$, and resuspended in $200 \mu \mathrm{l}$ of lysis buffer (50 mM Tris- $\mathrm{HCl}, \mathrm{pH} 7.6,100 \mathrm{mM}$ $\mathrm{NaCl}, 5 \mathrm{mM}$ EDTA, $0.5 \%$ SDS) supplemented with RNase (Roche Applied Science, $100 \mu \mathrm{g} / \mathrm{ml}$ ). After incubation at $37{ }^{\circ} \mathrm{C}$ for $20 \mathrm{~min}$, Proteinase K (Invitrogen, $200 \mu \mathrm{g} / \mathrm{ml}$ ) was added into the samples and incubated at $55^{\circ} \mathrm{C}$ for $3 \mathrm{~h}$. After phenol/chloroform extraction and ethanol precipitation, DNA was resuspended in $\mathrm{H}_{2} \mathrm{O}$. Equal amounts of DNA samples were separated on a $1.2 \%$ agarose gel and detected with ethidium bromide.

\section{Chromatin immunoprecipitation-quantitative PCR}

The chromatin immunoprecipitation (ChIP) Kit was purchased from Millipore (Cat No. 17-10086) and ChIP 
experiments were carried out essentially in accordance with manufacturer's guidelines. Immnuoprecipitated DNA was amplified with the designated primers on the Roche LightCycler480. The sequences of PCR primers were listed in Supplementary Table 2.

\section{SA- $\beta$-gal staining}

SA- $\beta$-gal staining was performed as described [39].

\section{Co-IP assay}

Co-IP assay was performed as described [39].

\section{Peptide pull-down assays}

Unmethylated and asymmetric dimethylated $\mathrm{N}$-terminal biotinylated peptides containing 20 aa of histone H4, were synthesized by GL Biochem Ltd. (Shanghai, China), and purified by HPLC. The final products attained $95 \%$ purity and were confirmed by electrospray ionization-MS (ESI-MS). Peptide pull-down assay was performed as described [40].

\section{Immunohistochemistry}

Immunohistochemistry was performed on paraffinembedded human skin sections of eyelid from plastic surgery of First Hospital of Jilin University. Formalin-fixed paraffin-embedded sections were deparaffinized and rehydrated by passage through xylene and a graded alcohol series. After antigen retrieval was performed by incubation in boiling citrate buffer, endogenous peroxidase activity was inactivated by treatment with $3 \%$ hydrogen peroxide. Sections were blocked in 5\% serum for $1 \mathrm{~h}$, and then incubated with primary antibody for $1.5 \mathrm{~h}$ at room temperature. Sections were then incubated in secondary antibody for $1 \mathrm{~h}$ at room temperature and the staining was visualized with DAB.

\section{Statistical analysis}

Data were compiled from at least three independent, replicate experiments. Data are presented as mean $\pm \mathrm{SD}$. The paired Student's $t$-test (two-tailed) was used to calculate the statistical significance of differences between groups. The $p<0.05$ was considered statistically significant. Statistical analysis was carried out using the GraphPad Prism software (GraphPad Software, La Jolla, CA, USA).

Acknowledgements This work was supported by the grants from the National Natural Science Foundation of China (grant numbers: 31771335 , $31770825,31571317,20180101232 \mathrm{JC}$, and 20140204003YY) and the
Science and Technology Development Project of Jilin Province (grant numbers: 20180101232JC and 20180101234JC).

\section{Compliance with ethical standards}

Conflict of interest The authors declare that they have no conflict of interest.

Publisher's note Springer Nature remains neutral with regard to jurisdictional claims in published maps and institutional affiliations.

\section{References}

1. Ben-Porath I, Weinberg RA. The signals and pathways activating cellular senescence. Int J Biochem Cell Biol. 2005;37:961-76.

2. O'Sullivan RJ, Kubicek S, Schreiber SL, Karlseder J. Reduced histone biosynthesis and chromatin changes arising from a damage signal at telomeres. Nat Struct Mol Biol. 2010;17:1218-25.

3. Liu L, Cheung TH, Charville GW, Hurgo BM, Leavitt T, Shih J, et al. Chromatin modifications as determinants of muscle stem cell quiescence and chronological aging. Cell Rep. 2013;4:189-204.

4. Hu Z, Chen K, Xia Z, Chavez M, Pal S, Seol JH, et al. Nucleosome loss leads to global transcriptional up-regulation and genomic instability during yeast aging. Genes Dev. 2014;28:396-408.

5. Bochkis IM, Przybylski D, Chen J, Regev A. Changes in nucleosome occupancy associated with metabolic alterations in aged mammalian liver. Cell Rep. 2014;9:996-1006.

6. Feser J, Truong D, Das C, Carson JJ, Kieft J, Harkness T, et al. Elevated histone expression promotes life span extension. Mol Cell 2010;39:724-35.

7. Campos EI, Reinberg D. Histones: annotating chromatin. Annu Rev Genet. 2009;43:559-99.

8. Gruosso T, Mieulet V, Cardon M, Bourachot B, Kieffer Y, Devun $\mathrm{F}$, et al. Chronic oxidative stress promotes $\mathrm{H} 2 \mathrm{AX}$ protein degradation and enhances chemosensitivity in breast cancer patients. EMBO Mol Med. 2016;8:527-49.

9. Singh RK, Kabbaj MH, Paik J, Gunjan A. Histone levels are regulated by phosphorylation and ubiquitylation-dependent proteolysis. Nat Cell Biol. 2009;11:925-33.

10. Qian MX, Pang Y, Liu CH, Haratake K, Du BY, Ji DY, et al. Acetylation-mediated proteasomal degradation of core histones during DNA repair and spermatogenesis. Cell. 2013;153:1012-24.

11. Bedford MT, Clarke SG. Protein arginine methylation in mammals: who, what, and why. Mol Cell. 2009;33:1-13.

12. Wang H, Huang ZQ, Xia L, Feng Q, Erdjument-Bromage H, Strahl BD, et al. Methylation of histone $\mathrm{H} 4$ at arginine 3 facilitating transcriptional activation by nuclear hormone receptor. Sci (New York, NY). 2001;293:853-7.

13. Strahl BD, Briggs SD, Brame CJ, Caldwell JA, Koh SS, Ma H, et al. Methylation of histone $\mathrm{H} 4$ at arginine 3 occurs in vivo and is mediated by the nuclear receptor coactivator PRMT1. Curr Biol. 2001;11:996-1000.

14. Zhang XS, Wang T, Lin XW, Denlinger DL, Xu WH. Reactive oxygen species extend insect life span using components of the insulin-signaling pathway. Proc Natl Acad Sci USA. 2017;114: E7832-e40.

15. Takahashi Y, Daitoku H, Hirota K, Tamiya H, Yokoyama A, Kako K, et al. Asymmetric arginine dimethylation determines life span in C. elegans by regulating forkhead transcription factor DAF-16. Cell Metab. 2011;13:505-16.

16. Lim Y, Lee E, Lee J, Oh S, Kim S. Down-regulation of asymmetric arginine methylation during replicative and $\mathrm{H}_{2} \mathrm{O}_{2}$-induced premature senescence in WI-38 human diploid fibroblasts. J Biochem. 2008;144:523-9. 
17. Gao Y, Zhao Y, Zhang J, Lu Y, Liu X, Geng P, et al. The dual function of PRMT1 in modulating epithelial-mesenchymal transition and cellular senescence in breast cancer cells through regulation of ZEB1. Sci Rep. 2016;6:19874.

18. Barzilai N, Crandall JP, Kritchevsky SB, Espeland MA. Metformin as a tool to target aging. Cell Metab. 2016;23:1060-5.

19. Bhullar KS, Hubbard BP. Lifespan and healthspan extension by resveratrol. Biochimica et biophysica acta. 2015;1852:1209-18.

20. Ehninger D, Neff F, Xie K. Longevity, aging and rapamycin. Cell Mol life Sci. 2014;71:4325-46.

21. Morales Y, Nitzel DV, Price OM, Gui S, Li J, Qu J, et al. Redox control of protein arginine methyltransferase 1 (PRMT1) activity. J Biol Chem. 2015;290:14915-26.

22. Hwang ES, Yoon G, Kang HT. A comparative analysis of the cell biology of senescence and aging. Cell Mol life Sci. 2009;66:2503-24.

23. Cho S, Hwang ES. Status of mTOR activity may phenotypically differentiate senescence and quiescence. Molecules cells. 2012;33:597-604.

24. Narita M, Nunez S, Heard E, Narita M, Lin AW, Hearn SA, et al. $\mathrm{Rb}$-mediated heterochromatin formation and silencing of E2F target genes during cellular senescence. Cell. 2003;113:703-16.

25. Hernandez-Segura A, Nehme J, Demaria M. Hallmarks of cellular senescence. Trends Cell Biol. 2018;28:436-53.

26. Coppe JP, Patil CK, Rodier F, Sun Y, Munoz DP, Goldstein J, et al. Senescence-associated secretory phenotypes reveal cellnonautonomous functions of oncogenic RAS and the p53 tumor suppressor. PLoS Biol. 2008;6:2853-68.

27. Dimri GP, Lee X, Basile G, Acosta M, Scott G, Roskelley C, et al. A biomarker that identifies senescent human cells in culture and in aging skin in vivo. Proc Natl Acad Sci USA. 1995;92:9363-7.

28. Salmonowicz H, Passos JF. Detecting senescence: a new method for an old pigment. Aging Cell. 2017;16:432-4.

29. Coppe JP, Desprez PY, Krtolica A, Campisi J. The senescenceassociated secretory phenotype: the dark side of tumor suppression. Annu Rev Pathol. 2010;5:99-118.
30. Hernandez-Segura A, de Jong TV, Melov S, Guryev V, Campisi J, Demaria M. Unmasking transcriptional heterogeneity in senescent cells. Curr Biol. 2017;27:2652-60.e4.

31. He S, Sharpless NE. Senescence in health and disease. Cell 2017;169:1000-11.

32. Celeste A, Petersen S, Romanienko PJ, Fernandez-Capetillo O, Chen HT, Sedelnikova OA, et al. Genomic instability in mice lacking histone H2AX. Sci (N. Y, NY). 2002;296:922-7.

33. Sancar A, Lindsey-Boltz LA, Unsal-Kacmaz K, Linn S. Molecular mechanisms of mammalian DNA repair and the DNA damage checkpoints. Annu Rev Biochem. 2004;73:39-85.

34. Fabbrizio E, El Messaoudi S, Polanowska J, Paul C, Cook JR, Lee $\mathrm{JH}$, et al. Negative regulation of transcription by the type II arginine methyltransferase PRMT5. EMBO Rep. 2002;3:641-5.

35. Schiza V, Molina-Serrano D, Kyriakou D, Hadjiantoniou A, Kirmizis A. N-alpha-terminal acetylation of histone $\mathrm{H} 4$ regulates arginine methylation and ribosomal DNA silencing. PLoS Genet. 2013;9:e1003805.

36. Ju J, Chen A, Deng Y, Liu M, Wang Y, Wang Y, et al. NatD promotes lung cancer progression by preventing histone $\mathrm{H} 4$ serine phosphorylation to activate Slug expression. Nat Commun. 2017;8:928.

37. Osmulski PA, Gaczynska M. Rapamycin allosterically inhibits the proteasome. Mol Pharmacol. 2013;84:104-13.

38. Wang R, Li Q, Helfer CM, Jiao J, You J. Bromodomain protein Brd4 associated with acetylated chromatin is important for maintenance of higher-order chromatin structure. J Biol Chem. 2012;287:10738-52

39. Zhao L, Zhang Y, Gao Y, Geng P, Lu Y, Liu X, et al. JMJD3 promotes SAHF formation in senescent WI38 cells by triggering an interplay between demethylation and phosphorylation of RB protein. Cell Death Differ. 2015;22:1630-40.

40. Geng P, Zhang Y, Liu X, Zhang N, Liu Y, Liu X, et al. Automethylation of protein arginine methyltransferase 7 and its impact on breast cancer progression. FASEB J. 2017;31: 2287-300. 